\title{
Unique Properties of Coactivator Recruitment Caused by Differential Binding of FK614, an Anti-diabetic Agent, to Peroxisome Proliferator- Activated Receptor $\gamma$
}

\author{
Takao Fujimura, ${ }^{* a}$ Hiroyuki Sakuma,,${ }^{a}$ Akiko Ohkubo-Suzuki, ${ }^{b}$ Ichiro Aramori, ${ }^{b}$ and \\ Seitaro $\mathrm{MuTOH}^{a}$ \\ ${ }^{a}$ Pharmacology Research Laboratories, Astellas Pharma Inc.; 2-1-6 Kashima, Yodogawa-ku, Osaka 532-8514, Japan: \\ and ${ }^{b}$ Molecular Medicine Research Laboratories, Astellas Pharma Inc.; 21 Miyukigaoka, Tsukuba, Ibaraki 305-8585, \\ Japan. Received September 23, 2005; accepted November 24, 2005; published online December 5, 2005
}

FK614 is a structurally novel class of peroxisome proliferator-activated receptor $\gamma(\operatorname{PPAR} \gamma)$ agonist, with the mechanism of its insulin-sensitizing action most likely due to activation of PPAR $\gamma$. In this study, properties of FK614 for PPAR $\gamma$ binding, ability to induce conformational change, and coactivator recruitment were investigated. FK614, rosiglitazone, and pioglitazone competed specific binding of $\left.{ }^{3} \mathrm{H}\right]$ rosiglitazone to PPAR $\gamma$ with $K_{\mathrm{i}}$ values of $11 \mathrm{nM}, 47 \mathrm{nM}$, and $1.3 \mu_{\mathrm{M}}$, respectively. Limited trypsin digestion of PPAR $\gamma$ with FK614 or rosiglitazone produced distinct patterns of digested polypeptides, suggesting that FK614 directly binds to PPAR $\gamma$ but induces specific alterations in receptor conformation. FK614 induced interaction of PPAR $\gamma$ with nuclear receptor coactivator CBP but of lower magnitude than rosiglitazone and pioglitazone. The estimated $K_{d}$ values of FK614-, rosiglitazone-, and pioglitazone-PPAR $\gamma$ complex to CBP peptide were $1.8,0.64$, and $0.72 \mu \mathrm{M}$, respectively, indicating FK614-PPAR $\gamma$ complex exhibits a lower affinity for CBP peptide compared to other agonist-PPAR $\gamma$ complexes. When tested the effect of FK614 on CBP recruitment induced by $9(S)$-hydroxyoctadecadienoic acid, an endogenous ligand, FK614 negatively modulated PPAR $\gamma$ activation. The unique properties of FK614 may underlie the molecular basis of ligand-dependent transcriptional modulation mediated by PPAR $\gamma$.

Key words FK614; coactivator recruitment; non-thiazolidinedione; peroxisome proliferator-activated receptor $\gamma($ PPAR $\gamma)$ modulator; anti-diabetes

Thiazolidinedione (TZD) compounds, such as rosiglitazone and pioglitazone, are anti-diabetic agents that improve insulin resistance. The action of TZDs is due to activation of peroxisome proliferator-activated receptor $\gamma(\operatorname{PPAR} \gamma)$, a member of the nuclear hormone receptor (NHR) family of ligand-activated transcription factors. ${ }^{1,2}$ However, since weight gain and edema have been reported as side effects of these drugs, ${ }^{3)}$ improvement of PPAR $\gamma$ agonists as anti-diabetic agents is still required. Furthermore, to offer a promising therapeutic approach to not only diabetes but also metabolic syndrome, new types of PPAR $\gamma$ agonists, that can improve dyslipidemia, are likely to be beneficial.

Under physiological conditions, activity of PPAR $\gamma$ is controlled by endogenous ligands. 9(S)-Hydroxyoctadecadienoic acid (HODE), which is one of the most potent endogenous ligands, ${ }^{4)}$ is an oxidation product of linoleic acid and a major oxidized lipid component of oxidized low density lipoprotein (LDL), ${ }^{5)}$ present at high levels in atherosclerotic lesions. $\left.{ }^{6}\right)$ $9(S)$-HODE is able to directly bind to PPAR $\gamma$ with affinities in the micromolar range and activate transcription of PPAR $\gamma$ target genes. ${ }^{4)}$ PPAR $\gamma$ and $9(S)$-HODE are reported to be involved in many cellular events, including fatty acid influx, foam cell formation, ${ }^{4)}$ vascular endothelial growth factor (VEGF) expression, ${ }^{7}$ ) and cholesterol efflux in macrophages. ${ }^{8,9)}$ Olefsky and Saltiel have suggested that PPAR $\gamma$ activators might not function purely as agonists for the receptor, but also antagonize the effects of endogenous ligands. ${ }^{10,11)}$

Several lines of studies have suggested that the binding of different PPAR $\gamma$ ligands can induce a range of distinct PPAR $\gamma$ conformations. ${ }^{12-15)}$ Conformational differences in ligand-PPAR $\gamma$ complexes lead to differential interactions with cofactors and exert differential regulation of activation on PPAR $\gamma$-responsible genes. ${ }^{10,16)}$ Such cofactors interact with NHRs and they can either repress or enhance transcriptional activities. ${ }^{17)}$ In general, an unactivated NHR is complexed with a corepressor, such as nuclear receptor corepressor (NCoR), which extinguishes their transcriptional activity by histone deacetylase, when ligand is absent. ${ }^{18)}$ Upon binding with agonists, an NHR undergoes a conformational change that promotes the recruitment of coactivators, such as cyclic AMP response element-binding protein (CREB)-binding protein $(\mathrm{CBP})^{19)}$ and steroid receptor coactivator $1,{ }^{20)}$ that have histone acetyltransferase activity. Coactivator complexes facilitate target gene transcription by local chromatin remodeling ${ }^{21)}$ and bridging between an NHR and basal transcriptional machineries. ${ }^{22)}$

Recently, we reported that the novel non-TZD compound [3-(2,4-dichlorobenzyl)-2-methyl- $N$-(pentylsulfonyl)-3- $H$ benzimidazole-5-carboxamide] (FK614) substantially improves hyperglycemia, hypertriglyceridemia, hyperinsulinemia, and glucose intolerance in genetically obese and diabetic animal models. ${ }^{23)}$ FK614 has been shown to promote PPAR $\gamma$-mediated transcription in a cell-based reporter gene assay, ${ }^{23)}$ suggesting that FK614 exerts its pharmacological effects through PPAR $\gamma$ activation. Despite FK614 producing a robust anti-diabetic effect in vivo, this compound appears to be a partial agonist of PPAR $\gamma$ mediated transactivation in vitro ${ }^{23)}$ Considering that FK614 behaves as a partial agonist of PPAR $\left.\gamma,{ }^{23}\right)$ it is likely that antagonistic cross talk exists between FK614 and endogenous ligands. In this study, whether FK614 directly induces conformational changes in PPAR $\gamma$, produces specific alterations in PPAR $\gamma$ conformation, and induces differential interaction with coactivators compared to 
other PPAR $\gamma$ ligands was examined. Furthermore, whether FK614 negatively regulates the biological responses evoked by endogenous ligands was also investigated.

\section{MATERIALS AND METHODS}

Materials Materials were obtained from the following sources: Escherichia coli BL21 and BL21(DE3)pLysS was purchased from Stratagene (La Jolla, CA, U.S.A.). $\left[{ }^{3} \mathrm{H}\right]-$ rosiglitazone, $\left[{ }^{35} \mathrm{~S}\right]$ methionine, and glutathione-Sepharose $4 \mathrm{~B}$ beads were from Amersham Bioscience (Piscataway, NJ, U.S.A.). Trypsin was purchased from Sigma (St. Louis, MO, U.S.A.). FK614, rosiglitazone, and pioglitazone were synthesized at Astellas Pharma Inc. (Tokyo, Japan). 9( $S)$-HODE was purchased from Larodan Fine Chemicals (Malmö, Sweden). Streptavidin-conjugated allophycocyanin (SA-APC) and europium-conjugated anti-glutathione S-transferase (GST) antibody (Eu-anti-GST antibody) were from PerkinElmer Life and Analytical Sciences (Boston, MA, U.S.A.), respectively. All other chemicals and reagents were purchased from Sigma or Nacalai Tesque (Kyoto, Japan).

Plasmids Human PPAR $\gamma 1$ and PPAR $\gamma 2^{24)}$ were cloned by reverse transcriptase-polymerase chain reaction (RT-PCR) with human adipose tissue and liver cDNA as templates, respectively. Full length cDNA for human PPAR $\gamma 1$ was cloned into pCDM8 (Invitrogen, Carlsbad, CA, U.S.A.). The resultant plasmid, pCDM8-hPPAR $\gamma 1$, was used for in vitro translation of human PPAR $\gamma 1$. Expression plasmids for GST fusion protein were generated by insertion of full-length human PPAR $\gamma 2$ or the ligand-binding domain (LBD) of human PPAR $\gamma$ into pGEX-4T-3 or pGEX-4T-2 vector (Amersham Bioscience), respectively. Full length cDNA for human $\mathrm{CBP}^{19)}$ was amplified by RT-PCR with human lung cDNA as template and cloned into pcDNA3.1 (Invitrogen). The resultant plasmid, pcDNA3.1-hCBP, was used for in vitro translation of human CBP.

Ligand Binding Assay LBD of human PPAR $\gamma$ was expressed as a GST fusion protein (GST-hPPAR $\gamma \mathrm{LBD}$ ) in $E s$ cherichia coli strain BL21(DE3)pLysS. Pelleted cells were lysed and the soluble extract was clarified by centrifugation. Bacterial lysates containing GST-hPPAR $\gamma$ LBD were stored at $4{ }^{\circ} \mathrm{C}$ after measurement of protein concentration and dilution. Control extracts containing GST alone were also prepared for non-specific binding. Bacterial extract containing GST-hPPAR $\gamma$ LBD or GST alone was incubated on ice for $3 \mathrm{~h}$ with $15 \mathrm{~nm}\left[{ }^{3} \mathrm{H}\right]$ rosiglitazone, in the absence or presence of unlabeled test compounds in binding buffer (10 mM Tris$\mathrm{HCl}, \mathrm{pH} 8.0,50 \mathrm{~mm} \mathrm{KCl}, 10 \mathrm{~mm}$ DTT). Bound radioactivity was separated from free radioactivity by elution through a Sephadex G-25 column (Roche Diagnostics, Basel, Switzerland). Amount of bound $\left[{ }^{3} \mathrm{H}\right]$ rosiglitazone was determined by liquid scintillation counting. Experiments were performed 3 times. Hill coefficients and $\mathrm{IC}_{50}$ values were calculated using GraphPad Prism (GraphPad Software, San Diego, CA, U.S.A.). $K_{\mathrm{i}}$ values were calculated according to the equation proposed by Cheng and Prusoff ${ }^{25)}: K_{\mathrm{i}}=\mathrm{IC}_{50} /\left(1+[\mathrm{L}] / K_{\mathrm{d}}\right)$, where [L] is concentration of $\left[{ }^{3} \mathrm{H}\right]$ rosiglitazone $(15 \mathrm{nM})$ and $K_{\mathrm{d}}$ for rosiglitazone is $69 \mathrm{~nm}$.

Limited Protease Sensitivity Assay pCDM8-hPPAR $\gamma 1$ plasmids were used to synthesize $\left[{ }^{35} \mathrm{~S}\right]$ methionine-labeled full length human PPAR $\gamma 1$ in a coupled transcription/transla- tion system (Promega, Madison, WI, U.S.A.). Transcription/ translation reactions were equally aliquoted, then diluted test compounds were added. These mixtures were incubated for $30 \mathrm{~min}$ at room temperature, then distilled water or increasing concentrations of trypsin was added. Protease digestion was allowed to proceed for $20 \mathrm{~min}$ at $25^{\circ} \mathrm{C}$, then was terminated by addition of SDS sample loading buffer and boiled for $1 \mathrm{~min}$ at $100^{\circ} \mathrm{C}$. Resulting solutions were resolved by SDS-PAGE, then radio-labeled digestion products were visualized by autoradiography using a bio-imaging analyzer BAS2000 (Fuji Photo Film, Tokyo, Japan). Autoradiograms were analyzed using image analyzing software (ATTO Densito Graph 4.0, ATTO, Tokyo, Japan), and molecular mass of protected fragments was measured. Experiments were performed 3 times. Measurement of molecular mass was performed in all 3 experiments, then the mean was calculated for 3 experiments.

GST Pull-Down Assay Full-length human PPAR $\gamma 2$ was expressed as a GST fusion protein (GST-hPPAR $\gamma 2$ ) in Escherichia coli strain BL21. GST-hPPAR $\gamma 2$ was purified using glutathione-Sepharose $4 \mathrm{~B}$ beads. $\left[{ }^{35} \mathrm{~S}\right]$ methionine-labeled human CBP was synthesized in a coupled transcription/translation system, using pcDNA3.1-hCBP as template. The obtained $\left[{ }^{35} \mathrm{~S}\right]$-labeled human CBP was incubated with GSThPPAR $\gamma 2$ and glutathione-Sepharose 4B beads in the presence or absence of compounds in binding buffer $(8 \mathrm{~mm}$ Tris- $\mathrm{HCl}, \mathrm{pH} 7.6,120 \mathrm{~mm} \mathrm{KCl,} \mathrm{8 \%} \mathrm{glycerol,} \mathrm{0.5 \%} \mathrm{3-[(3-}$ cholamidopropyl) dimethylammonio]-1-propane-sulfonate, $1 \mathrm{mg} / \mathrm{ml} \mathrm{BSA}, 1 \mathrm{~mm}$ DTT, $10 \mu \mathrm{g} / \mathrm{ml}$ aprotinin, $10 \mu \mathrm{g} / \mathrm{ml} \mathrm{leu-}$ peptin, $10 \mu \mathrm{g} / \mathrm{ml}$ pepstatin). These mixtures were incubated overnight at $4{ }^{\circ} \mathrm{C}$, and beads were washed 4 times to remove unbound coactivators. Bound proteins were extracted into SDS sample loading buffer, then separated by SDS-PAGE. Bound CBP was visualized by autoradiography and quantitated by counting radioactivity using a BAS2000. Experiments were performed 3 or 4 times. $\mathrm{EC}_{50}$ values for human CBP recruitment were determined by nonlinear curve fitting using Statistical Analysis System (SAS) (SAS Institute, Cary, $\mathrm{NC}$, U.S.A.). Each $\mathrm{EC}_{50}$ value was calculated under conditions where the maximum recruitment activity induced by each ligand was $100 \%$. Significant difference of the values of CBP recruitment between non-treated control group and each ligand treated groups was assessed by Dunnett's multiple comparisons using SAS. Statistical significance was assumed at $p<0.05$.

Homogeneous Time-Resolved Fluorescence (HTRF) Assay Amino acid sequences of cofactor peptides, tagged at the $\mathrm{N}$ termini with biotin, used in HTRF assays were as follows: human CBP (N-Biotin-SGNLVPDAASKHKQLSELLRGGSGS-C), ${ }^{19}$ ) human NCoR (N-Biotin-ADPASNLGLEDIIRKALMGSF-C). ${ }^{18)}$ GST-hPPAR $\gamma 2$ (50 nM) was incubated with $3 \mathrm{~nm}$ Eu-anti-GST antibody, $150 \mathrm{~nm}$ SA-APC, and $300 \mathrm{~nm}$ biotin-peptide in the absence or presence of compounds in $100 \mu \mathrm{l}$ of assay buffer (10 mM HEPES, pH 7.6, $1 \mathrm{~mm}$ DTT, $100 \mathrm{~mm} \mathrm{NaCl}, 0.05 \%$ Tween 20, $1 \mathrm{mg} / \mathrm{ml} \mathrm{BSA}$ ) for $16 \mathrm{~h}$ at $4{ }^{\circ} \mathrm{C}$. The assay was performed in a 96 -well black plate (Nalge Nunc International, Rochester, NY, U.S.A.) and fluorescence was measured using an ARVO HTS multilabel counter (PerkinElmer Life and Analytical Sciences). HTRF signal was expressed as the ratio of emission intensities at $665: 615 \mathrm{~nm}$ multiplied by a factor of 1000 . For saturation 
experiments, GST-hPPAR $\gamma 2$ (10 nM) was incubated with $5 \mathrm{~nm}$ Eu-anti-GST antibody, $600 \mathrm{~nm}$ SA-APC, in the presence of $10 \mu \mathrm{M}$ FK614, $10 \mu \mathrm{M}$ rosiglitazone, or $100 \mu \mathrm{M}$ pioglitazone with various concentrations of non-labeled and biotin-labeled CBP peptides with a molar ratio of $50: 1$, in $100 \mu$ l of assay buffer for $16 \mathrm{~h}$ at $4{ }^{\circ} \mathrm{C}$. Nonspecific binding was determined in the presence of $2 \mathrm{~mm}$ unlabeled CBP peptide. Specific binding of CBP peptide to human PPAR $\gamma 2$ is evaluated by subtracting the HTRF signal of nonspecific binding from the HTRF signal of total binding. Experiments were performed 3 times. $\mathrm{EC}_{50}$ values were determined by nonlinear curve fitting using $\mathrm{SAS}$. Each $\mathrm{EC}_{50}$ value for coactivator recruitment was calculated under conditions where the maximum recruitment activity induced by each ligand is $100 \% . \mathrm{EC}_{50}$ value for NCoR dissociation was calculated under conditions where the amount of NCoR binding to PPAR $\gamma$ in the absence of the ligand was $0 \%$ and HTRF signal in the absence of GSThPPAR $\gamma 2$ was $100 \%$. Estimated $K_{\mathrm{d}}$ values for CBP peptide binding to ligand-PPAR $\gamma$ complex were determined by linear regression analysis using GraphPad Prism.

\section{RESULTS}

Ability of FK614 to Interact Directly with PPAR $\gamma$ To determine whether activation of PPAR $\gamma$ by FK614 is due to direct binding of FK614 to PPAR $\gamma$, a competition binding assay was performed using $\left[{ }^{3} \mathrm{H}\right]$ rosiglitazone and GSThPPAR $\gamma$ LBD. FK614, rosiglitazone, and pioglitazone displaced $\left[{ }^{3} \mathrm{H}\right]$ rosiglitazone binding to GST-hPPAR $\gamma$ LBD in a concentration dependent manner (Fig. 1). This indicates that FK614 can bind directly to PPAR $\gamma$, similar to TZDs such as rosiglitazone and pioglitazone. It appears that FK614 is a high-affinity PPAR $\gamma$ ligand with a $K_{\mathrm{i}}$ value of $11 \mathrm{~nm}$. Binding affinity of FK614 was 4.3- and 120-fold higher than that of rosiglitazone $\left(K_{\mathrm{i}}: 47 \mathrm{nM}\right)$ and pioglitazone $\left(K_{\mathrm{i}}: 1.3 \mu \mathrm{M}\right)$, respectively (Table 1). FK614 shows a distinctly steeper slope of the displacement curve compared to rosiglitazone and pioglitazone (Fig. 1). The Hill coefficient for FK614, rosiglitazone, and pioglitazone was 3.2, 1.3, and 1.2, respectively. The distinct property of FK614 for binding to PPAR $\gamma$ is probably due to different conformational changes of the PPAR $\gamma$ in response to binding of alternative ligands.

Alteration in Conformations of PPAR $\gamma$ Induced by FK614 and Rosiglitazone To determine whether FK614 can directly induce conformational change in PPAR $\gamma$ and whether FK614 produces specific alterations in PPAR $\gamma$ conformation, the limited trypsin digestion of a full-length human PPAR $\gamma 1$ was performed. Human PPAR $\gamma 1$ labeled with $\left[{ }^{35} \mathrm{~S}\right]$ methionine was pre-incubated with dimethyl sulfoxide (DMSO) (vehicle), $10 \mu \mathrm{M}$ FK614, or $10 \mu \mathrm{M}$ rosiglitazone, then digested with various concentrations of trypsin (Fig. 2). Incubation of the receptor with various concentrations of trypsin in the absence of ligand led to complete digestion of human PPAR $\gamma 1$. In contrast, rosiglitazone produced protease resistant fragments, a major $22 \mathrm{kDa}$ and a minor $32 \mathrm{kDa}$ fragment, following partial protease digestion. The protease protection pattern was similar to previous results reported by Elbrecht et al. ${ }^{24)}$ FK614 also generated protease resistant fragments, however, a distinct digestion pattern was identified. FK614 induced stronger protection than rosiglitazone, and the $32 \mathrm{kDa}$ fragment was detected more

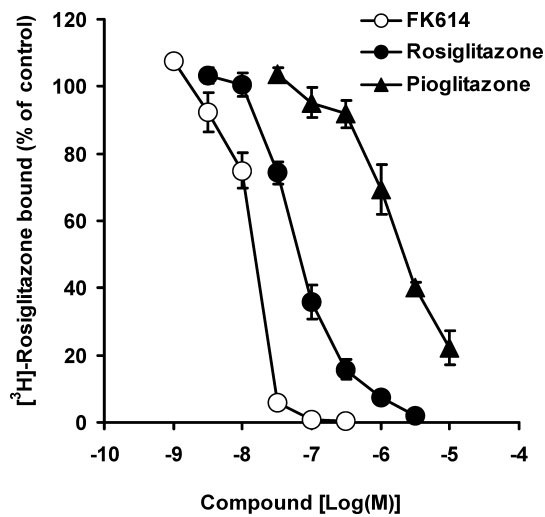

Fig. 1. Displacement of $\left[{ }^{3} \mathrm{H}\right]$ Rosiglitazone from GST-hPPAR $\gamma$ LBD by FK614, Rosiglitazone, and Pioglitazone

A competition binding assay was performed for $3 \mathrm{~h}$ with $15 \mathrm{~nm}\left[{ }^{3} \mathrm{H}\right]$ rosiglitazone in the absence or presence of indicated concentrations of unlabeled FK614 (open circle), rosiglitazone (closed circle), or pioglitazone (closed triangle). Results are presented as $\%$ of control. Values are mean \pm S.E. of 3 independent experiments. $K_{\mathrm{i}}$ values are listed in Table 1.

Table 1. $K_{\mathrm{i}}$ and $\mathrm{EC}_{50}$ Values for PPAR $\gamma$ Ligands in Binding, GST PullDown, and HTRF Assays

\begin{tabular}{|c|c|c|c|c|}
\hline \multirow{2}{*}{ Ligand } & \multirow{2}{*}{$\begin{array}{c}K_{\mathrm{i}}(\mathrm{nm}) \\
\text { in binding } \\
\text { assay }\end{array}$} & $\begin{array}{c}\mathrm{EC}_{50}(\mathrm{~nm}) \text { in } \\
\text { pull-down }\end{array}$ & \multicolumn{2}{|c|}{$\mathrm{EC}_{50}(\mathrm{nM})$ in HTRF assay } \\
\hline & & $\begin{array}{l}\text { Full length } \\
\text { CBP } \\
\text { recruitment }\end{array}$ & $\begin{array}{c}\text { CBP } \\
\text { peptide } \\
\text { recruitment }\end{array}$ & $\begin{array}{l}\text { NCoR } \\
\text { peptide } \\
\text { release }\end{array}$ \\
\hline FK614 & 11 & 3.6 & 3.7 & 10 \\
\hline Rosiglitazone & 47 & 31 & 17 & 61 \\
\hline Pioglitazone & 1300 & $>1200^{a)}$ & 200 & 1200 \\
\hline
\end{tabular}

a) The amount of full length CBP recruitment was not obtained at the saturating concentration for pioglitazone in GST pull-down assay, therefore $\mathrm{EC}_{50}$ value is estimated to be greater than $1200 \mathrm{~nm}$ for pioglitazone in that assay.
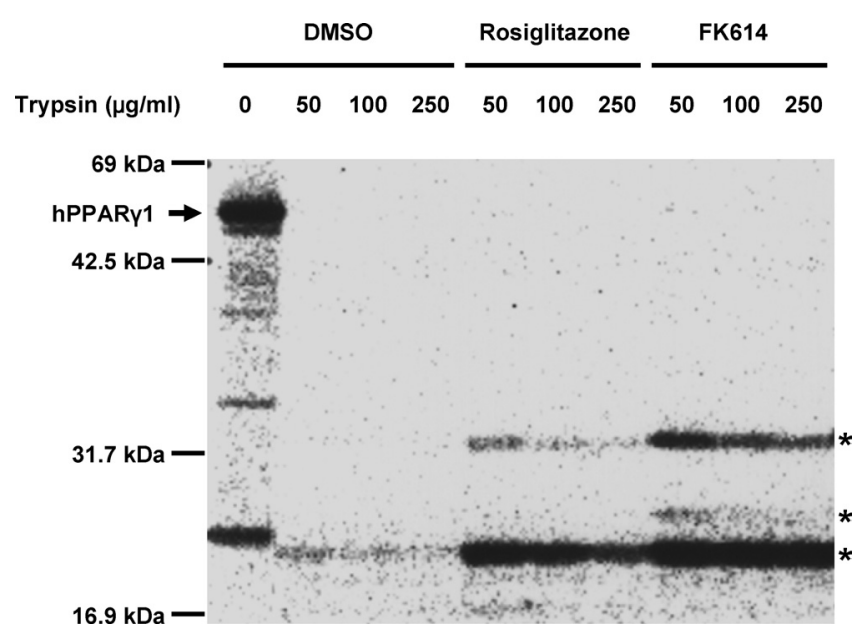

Fig. 2. Difference in Protease Sensitivity of FK614- and RosiglitazoneBound PPAR $\gamma$

Autoradiogram of a SDS-PAGE showing $\left[{ }^{35} \mathrm{~S}\right]$ methionine-labeled full length human PPAR $\gamma 1$ digested with increasing concentrations of trypsin $(0,50,100,250 \mu \mathrm{g} / \mathrm{ml})$ for $20 \mathrm{~min}$ at $25^{\circ} \mathrm{C}$. Receptor was pre-incubated with DMSO, $10 \mu \mathrm{M} \mathrm{FK} 614$, or $10 \mu \mathrm{m}$ rosiglitazone. Experiments were performed 3 times with similar results. Asterisk denotes trypsin-resistant protein fragments.

clearly than in the rosiglitazone-treated samples. In addition, a $25 \mathrm{kDa}$ fragment found in FK614-bound receptor was faintly detected. Thus the results indicate that these two lig- 


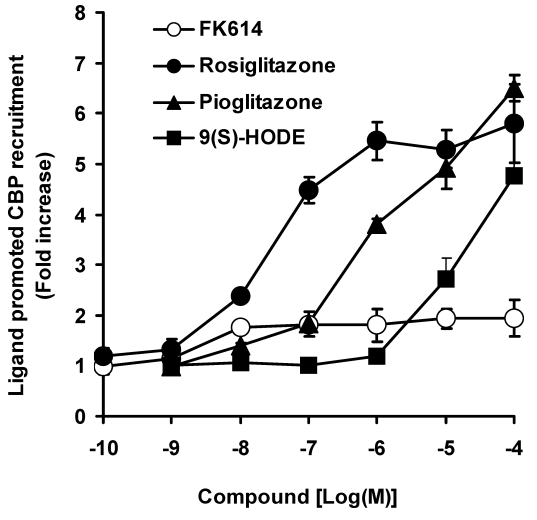

Fig. 3. Comparison of FK614-, Rosiglitazone-, Pioglitazone-, and 9(S)HODE-Induced CBP Recruitment to PPAR $\gamma$ in a GST Pull-Down Assay

GST-hPPAR $\gamma 2$ bound to glutathione-Sepharose 4B beads was incubated with $\left[{ }^{35} \mathrm{~S}\right]$ methionine-labeled human CBP in the absence or presence of indicated concentrations of FK614 (open circle), rosiglitazone (closed circle), pioglitazone (closed triangle), or $9(S)$-HODE (closed square) overnight at $4{ }^{\circ} \mathrm{C}$. After washing, bound proteins were eluted and analyzed by SDS-PAGE and autoradiography. $0.45 \pm 0.07 \%$ of total amount of ${ }^{35}$ S]-labeled human CBP bound to GST-hPPAR $\gamma 2$ in the absence of ligand. Results are presented as the fold increase relative to vehicle control, with mean \pm S.E. of 3 or 4 independent experiments shown. $\mathrm{EC}_{50}$ values are listed in Table 1.

ands interact with PPAR $\gamma$ directly and induce distinct PPAR $\gamma$ conformations.

Ligand Type-Specific Differential Interaction of PPAR $\gamma$ with Cofactors To determine whether FK614 directly promotes coactivator recruitment as an agonist and to address FK614-induced differential interaction with coactivators compared to other compounds, the effect of FK614, rosiglitazone, and pioglitazone on recruitment of CBP to PPAR $\gamma$ by GST pull-down assay was studied. GST-hPPAR $\gamma 2$ was incubated with $\left.{ }^{35} \mathrm{~S}\right]$ methionine-labeled human CBP in the absence or presence of various concentrations of ligands (Fig. $3)$. FK614, rosiglitazone, pioglitazone, and 9(S)-HODE promoted the recruitment of CBP to PPAR $\gamma$ in a concentration dependent manner. In response to rosiglitazone, an obvious increase in recruitment of CBP was obtained at $10 \mathrm{~nm}$, reaching a plateau at $1 \mu \mathrm{M}$. Maximal recruitment of CBP in rosiglitazone-bound receptor was approximately 6-fold above basal level. Induction of CBP recruitment for pioglitazone and $9(S)$-HODE was initiated at $10 \mathrm{~nm}$ and $1 \mu \mathrm{M}$, respectively, and maximal response was achieved at $100 \mu \mathrm{M}$ or higher. Magnitude of CBP binding to PPAR $\gamma$ at the highest concentration was similar in the 3 ligands. In contrast, FK614 exhibited a mechanistically different property in the concentration response curve for CBP recruitment. FK614 significantly promoted CBP recruitment to PPAR $\gamma$ at $10 \mathrm{~nm}$ and higher concentrations. Maximal level of CBP recruitment induced by FK614 was about 2-fold above basal level. These results indicate that FK614 can induce recruitment of CBP to PPAR $\gamma$ as a potent agonist for PPAR $\gamma$, and shows differential properties in coactivator recruitment compared to other ligands, presumably due to the distinct conformational change of PPAR $\gamma$ induced by FK614.

Transcriptional activity of PPAR $\gamma$ is regulated by dissociation or association with corepressors and coactivators in a ligand dependent manner. ${ }^{10)}$ To examine the effects of FK614 on coactivator or corepressor interaction, HTRF assays using peptides derived from the receptor interaction domain of corepressors or coactivators were performed. Figure 4A shows that HTRF signal was increased by recruitment of
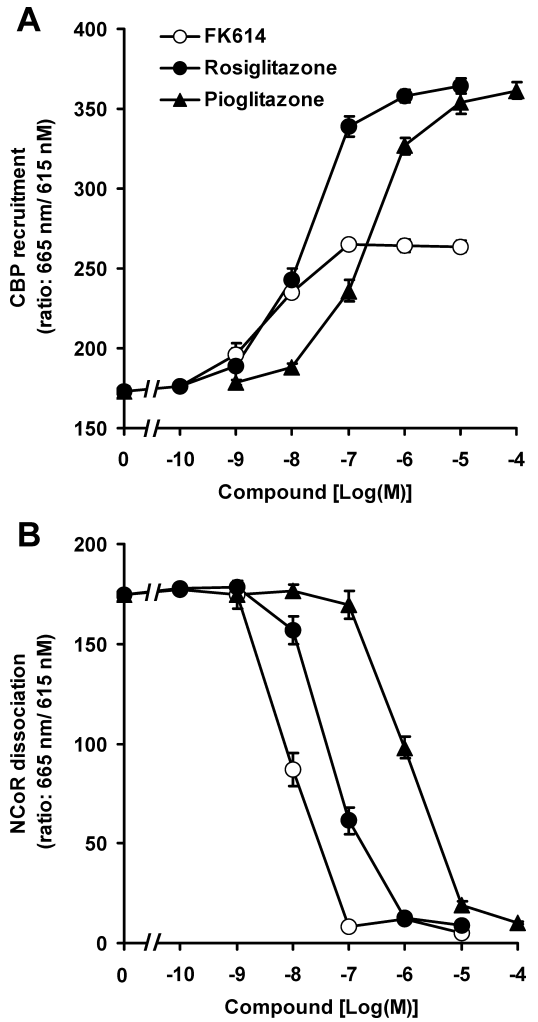

Fig. 4. PPAR $\gamma$-Cofactor Peptide Interaction Measured by HTRF Assay

Cofactor peptides from human CBP (A) and human NCoR (B) were used. Purified GST-hPPAR $\gamma 2$ (50 nM), Eu-anti-GST antibody (3 nM), SA-APC (150 nM) and biotinpeptide ( $300 \mathrm{~nm}$ ) were incubated with indicated concentrations of FK614 (open circle), rosiglitazone (closed circle), and pioglitazone (closed triangle) for $16 \mathrm{~h}$ at $4{ }^{\circ} \mathrm{C}$. HTRF signal was measured as the emission intensity ratio at $665: 615 \mathrm{~nm}$. Values are mean \pm S.E. of 3 independent experiments. $\mathrm{EC}_{50}$ values are listed in Table 1 .

peptide from human CBP in the presence of various concentrations of FK614, rosiglitazone, and pioglitazone. However, the maximum response of FK614 was lower than that of the other 2 compounds. Results were similar to those observed in GST pull-down assays using full-length human CBP. In the absence of ligand, NCoR-PPAR $\gamma$ interaction-dependent HTRF signal was observed, indicating that peptide from human NCoR was constitutively bound to PPAR $\gamma$ (Fig. 4B). FK614, rosiglitazone, and pioglitazone promoted dissociation of NCoR peptide from PPAR $\gamma$ in a concentration dependent manner (Fig. 4B). At $10 \mu \mathrm{M}$ FK614, $10 \mu \mathrm{M}$ rosiglitazone, and $100 \mu \mathrm{m}$ pioglitazone, the level of PPAR $\gamma$ binding to NCoR peptide was $2.8,5.0$, and $5.9 \%$ of control levels, respectively. These results indicate that FK614 promotes release of the constitutive interaction between corepressor and non-ligand bound PPAR $\gamma$ as efficaciously as rosiglitazone and pioglitazone. Using this assay, $\mathrm{EC}_{50}$ values of FK614, rosiglitazone, and pioglitazone for corepressor dissociation and coactivator recruitment were determined (Table 1). $\mathrm{EC}_{50}$ values of FK614 for CBP recruitment were 4.6- and 54-fold smaller than that of rosiglitazone and pioglitazone, respectively. FK614 was 6.1- and 120-fold more potent than rosiglitazone and pioglitazone, respectively, for NCoR dissociation. Interestingly, $\mathrm{EC}_{50}$ values of each compound for NCoR dissociation were higher than that for CBP recruitment. These results suggest that affinity of PPAR $\gamma$ ligands for corepressor-unbound PPAR $\gamma$ is higher than that for $\operatorname{PPAR} \gamma-\mathrm{NCoR}$ complex and that this is probably due to the conformational 

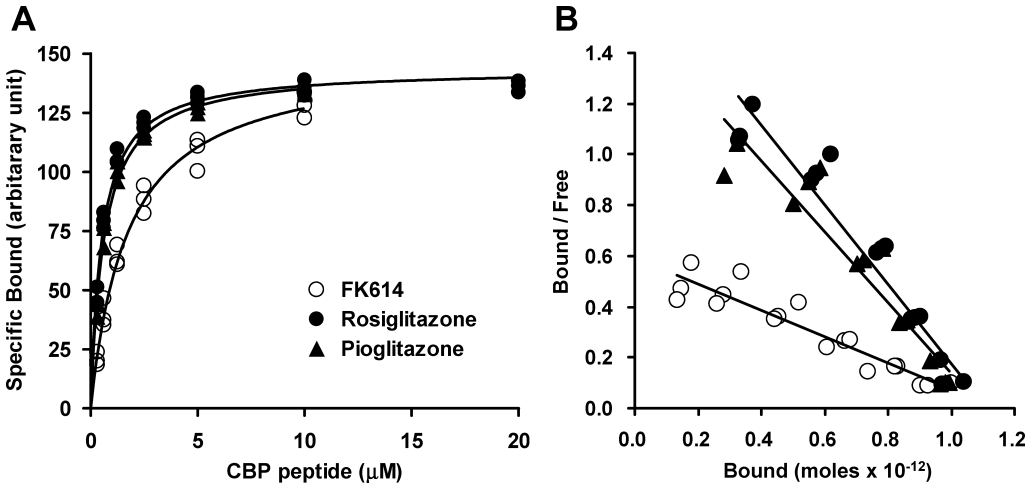

Fig. 5. Comparison of Affinity of Ligand-PPAR $\gamma$ Complex for CBP Peptide in HTRF Assay

A: Saturation analysis of CBP peptide binding to FK614, rosiglitazone, and pioglitazone-PPAR $\gamma$ complex. Purified GST-hPPAR $\gamma 2$ ( $10 \mathrm{~nm}$ ), Eu-anti-GST antibody (5 nM), and SA-APC (600 nM) were incubated with increasing concentrations of non-labeled and biotin-labeled CBP peptides at a molar ratio of $50: 1$, in the presence of $10 \mu \mathrm{M}$ of FK614 (open circle), $10 \mu \mathrm{M}$ rosiglitazone (closed circle), or $100 \mu \mathrm{M}$ pioglitazone (closed triangle) for $16 \mathrm{~h}$ at $4{ }^{\circ} \mathrm{C}$. HTRF signal was measured as the emission intensity ratio at $665: 615 \mathrm{~nm}$. Specific binding of CBP peptide to human PPAR $\gamma 2$ was evaluated by subtracting HTRF signal of nonspecific binding from HTRF signal of total binding. B: Scatchard analysis of CBP peptide binding to FK614- (open circle), rosiglitazone- (closed circle), or pioglitazone- (closed triangle) PPAR $\gamma$ complex. Experiments were performed 3 times. All data are shown.

change of PPAR $\gamma$ induced by the interaction of NCoR peptide with PPAR $\gamma$.

Affinity of Ligand-PPAR $\gamma$ Complex for Coactivator To investigate whether FK614 induces differential affinity of PPAR $\gamma$ for coactivator compared with other TZDs, estimated $K_{\mathrm{d}}$ values for the peptide from human CBP were determined using HTRF assays. Figure 5A shows saturation binding curves for CBP peptide in the presence of $10 \mu \mathrm{M}$ FK614, $10 \mu \mathrm{M}$ rosiglitazone, or $100 \mu \mathrm{m}$ pioglitazone. At $20 \mu \mathrm{M}$ CBP peptide, binding of CBP peptide to PPAR $\gamma$ was almost saturated in the presence of rosiglitazone. Since, it was assumed that HTRF signal indicates the amount of CBP peptide that binds to all PPAR $\gamma$, in the presence of $20 \mu \mathrm{M}$ CBP peptide and $10 \mu \mathrm{M}$ rosiglitazone. Furthermore, it has been shown by $\mathrm{X}$-ray crystal structure analysis that coactivators bind to $\operatorname{PPAR} \gamma$ at a ratio of $1 \mathrm{~mol}$ coactivator: $1 \mathrm{~mol} \operatorname{PPAR} \gamma$ in the presence of ligands. ${ }^{26,27)}$ Therefore, it was also assumed that CBP binding at saturation approaches a ratio of $1 \mathrm{~mol}$ coactivator: 1 mol PPAR $\gamma$. Amounts of free and bound CBP peptide under the all conditions were then estimated. Linear regression analysis of bound/free versus bound Scatchard transformation data yielded estimated $K_{\mathrm{d}}$ values of $1.9,0.64$, and $0.72 \mu \mathrm{M}$ in the presence of FK614, rosiglitazone, and pioglitazone, respectively (Fig. 5B). The estimated $K_{\mathrm{d}}$ value of FK614-PPAR $\gamma$ complex to CBP peptide was 3.0- and 2.7fold larger than that of rosiglitazone- and pioglitazone$\operatorname{PPAR} \gamma$ complex, respectively. These results indicate that FK614-PPAR $\gamma$ complex exhibits low affinity compared to other TZD-PPAR $\gamma$ complexes in CBP peptide binding, presumably due to the different conformational changes of PPAR $\gamma$ induced by FK614.

Negative Modulation of 9(S)-HODE-Induced Coactivator Recruitment to PPAR $\gamma$ by FK614 To address the possibility that FK614 negatively regulates biological responses evoked by endogenous ligands, the effect of FK614 on coactivator recruitment promoted by $9(S)$-HODE was examined by GST pull-down assay. As shown in Fig. 6, FK614 caused a concentration dependent decrease in magnitude of CBP binding to PPAR $\gamma$ induced by $9(S)$-HODE, inhibiting to the level obtained by stimulation with FK614 alone. This inhibitory effect was observed even at 10 nM FK614, which is in good agreement with results obtained in ligand binding

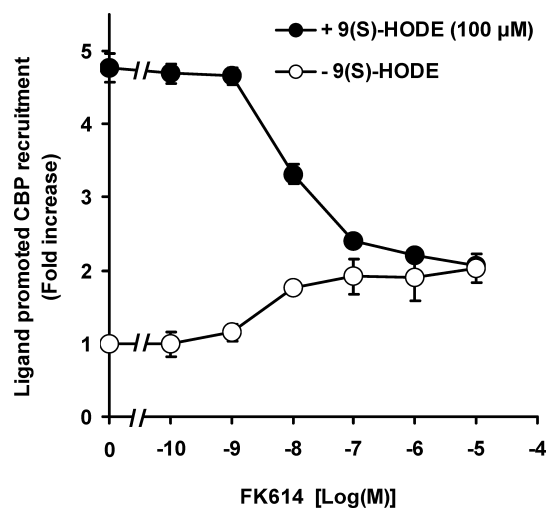

Fig. 6. Negative Modulation of 9(S)-HODE-Induced Coactivator Recruitment to PPAR $\gamma$ by FK614 in a GST Pull-Down Assay

GST-hPPAR $\gamma 2$ bound to glutathione-Sepharose 4B beads was incubated with $\left.{ }^{35} \mathrm{~S}\right]$ methionine-labeled human $\mathrm{CBP}$ at indicated concentrations of FK614 in the absence (open circle) or presence of $100 \mu \mathrm{M} 9(S)$-HODE (closed circle) overnight at $4{ }^{\circ} \mathrm{C}$ After washing bound proteins were eluted, then analyzed by SDS-PAGE and autoradiography. Results are presented as fold increase relative to vehicle control, with mean \pm S.E. of 3 independent experiments shown.

and FK614-promoted coactivator recruitment experiments. On the other hand, $10 \mu \mathrm{m}$ rosiglitazone did not inhibit CBP peptide recruitment to PPAR $\gamma$ induced by $9(S)$-HODE (data not shown). These results demonstrate that the biological effect of 9(S)-HODE, an efficacious endogenous agonist for $\operatorname{PPAR} \gamma$, can be modulated negatively by FK614.

\section{DISCUSSION}

FK614, a structurally novel class of PPAR $\gamma$ agonist incorporating a sulfonylcarbamoyl moiety as a key pharmacophore, improves hyperglycemia in diabetic $d b / d b$ mice. ${ }^{23)}$ FK614 has been shown to promote PPAR $\gamma$-mediated transcription in cell-based reporter gene assay, ${ }^{23}$ suggesting that FK614 exerts its pharmacological effects through PPAR $\gamma$ activation, like the previously reported rosiglitazone and pioglitazone. ${ }^{2)}$ In this study, FK614 behaved as a novel class of $\operatorname{PPAR} \gamma$ ligand with unique properties in PPAR $\gamma$ activation.

First, we focused on the binding of FK614 to PPAR $\gamma$ and the effect of FK614 on conformational change of PPAR $\gamma$. Competitive binding analysis showed that FK614 competes 
for binding of $\left[{ }^{3} \mathrm{H}\right]$ rosiglitazone to PPAR $\gamma$. In protease protection assays, FK614 altered protease sensitivity of PPAR $\gamma$ and generated ligand-like protection patterns ${ }^{24,28)}$ that can be observed in rosiglitazone-bound receptor. These results clearly indicate that FK614 can directly bind to PPAR $\gamma$ and induce a conformational change in PPAR $\gamma$. In the binding assay, FK614 showed a distinctly steeper slope for the displacement curve. Furthermore, in limited protease sensitivity assay, FK614 induced a stronger protection of the $32 \mathrm{kDa}$ fragment, also the $25 \mathrm{kDa}$ fragment, that was not present in rosiglitazone-treated samples, was faintly detected in FK614bound receptor. These observed differences strongly suggest that the conformational changes induced by FK614 in $\operatorname{PPAR} \gamma$ were slightly different from those by TZD compounds, presumably because FK614 interacts with PPAR $\gamma$ in a different manner. These results show that FK614 can alter the conformation of PPAR $\gamma$ upon direct binding and suggest that it could lead to differential biological responses compared to other TZDs, while those compounds act on PPAR $\gamma$ as a primary site of action. The coefficient of Hill plot for FK614 was higher than that for other TZD compounds. This observation suggests a positive cooperative interaction of FK614 with PPAR $\gamma$. Although further investigation is required to characterize the mechanism of interaction of FK614 with PPAR $\gamma$, it may be possible that dimerization of the receptor ${ }^{26)}$ exhibits a cooperative interaction, like interaction of estradiol with the estrogen receptor. ${ }^{29)}$ Binding of FK614 to one component of a possible PPAR $\gamma$ homodimer may lead to an allosteric conformational change enhancing the affinity of the other unoccupied component for FK614. Alternatively, similar to 4-hydroxytamoxifen binding that inhibits estradiol binding to estrogen receptor, ${ }^{30)}$ PPAR $\gamma$ may have different binding sites for FK614 and rosiglitazone, and binding of FK614 to PPAR $\gamma$ may reduce the affinity of rosiglitazone binding to $\operatorname{PPAR} \gamma$.

Second, we focused on the interaction between transcriptional cofactors and PPAR $\gamma$, and examined the effects of FK614, rosiglitazone, and pioglitazone on the recruitment of coactivator to PPAR $\gamma$ in vitro. FK614, as well as other compounds, promotes corepressor release and coactivator recruitment to PPAR $\gamma$, behaving as a PPAR $\gamma$ agonist. In this study, the maximal effect of FK614 in coactivator recruitment was much lower than other compounds, as the FK614-PPAR $\gamma$ complex exhibits lower affinity for the CBP peptide than other ligand-PPAR $\gamma$ complexes. In previous studies, the maximal effect of FK614 on PPAR $\gamma$ mediated transcription in cell-based reporter gene assay was lower than other compounds, such as rosiglitazone and pioglitazone. ${ }^{23)}$ This strongly suggests that the partial-agonistic feature of FK614 observed in reporter gene assay is due to the lower magnitude of recruitment of coactivators to FK614-PPAR $\gamma$ complexes. The effect of rosiglitazone on CBP recruitment was initiated at a concentration of $10 \mathrm{~nm}$, increasing gradually to reach a plateau at $1 \mu \mathrm{M}$. FK614-induced recruitment was also initiated at a concentration of the same order of magnitude as rosiglitazone, in the plateau. These observations are consistent with the rank order of potencies in the binding study. Interestingly, estimated $K_{\mathrm{d}}$ value of FK614-PPAR $\gamma$ complex was larger than that of rosiglitazone- and pioglitazonePPAR $\gamma$ complex in CBP peptide binding. These results suggest that FK614 is a potent ligand for receptor occupancy, but produces receptor conformations with reduced affinity for coactivators. Thus, FK614 behaves as a high affinity ligand for PPAR $\gamma$ with low intrinsic activity. Therefore, at this point FK614 is clearly distinguishable from other TZD compounds.

Finally, we focused on the possibility that FK614 negatively modulates PPAR $\gamma$-activity induced by endogenous ligand, and examined the effect of FK614 on 9(S)-HODE-induced coactivator recruitment using GST pull-down assay. $9(S)$-HODE promoted coactivator recruitment to PPAR $\gamma$ and behaved as a PPAR $\gamma$ agonist. Magnitude of coactivator recruitment achieved by $9(S)$-HODE was greater than that of the maximal response of FK614, indicating that 9(S)-HODE is more efficacious than FK614. FK614 caused a concentration-dependent decrease in the magnitude of CBP binding to PPAR $\gamma$ induced by $9(S)$-HODE and inhibited the level obtained when stimulated by FK614 alone. This inhibitory effect was observed even at low concentrations of FK614, which is in good agreement with results obtained in ligand binding and FK614-promoted coactivator recruitment experiments. As FK614 is a potent ligand in receptor occupancy, FK614 competes effectively with $100 \mu \mathrm{M} 9(S)$-HODE even at low concentrations. The results described above indicate that, unlike the full-agonists, FK614 negatively modulates PPAR $\gamma$-activity induced by $9(S)$-HODE. High concentrations of $9(S)$-HODE were required to obtain activation of coactivator recruitment. In tissues containing high amounts of $9(S)$ HODE, such as macrophage, biological effects mediated by such endogenous ligands may be negatively regulated by FK614. Thus, FK614 could behave as a tissue- and stagespecific PPAR $\gamma$ modulator that activates or represses PPAR $\gamma$ mediated pathways, depending on the cell context of target tissues. 9 $(S)$-HODE is an oxidative metabolite of linoleic acid, a major oxidized lipid component of oxidized LDL, ${ }^{4,5}$ and is present at high levels in atherosclerotic lesions. $\left.{ }^{6}\right) 9(S)$ HODE-mediated PPAR $\gamma$ activation is involved in many cellular events, including fatty acid influx, ${ }^{4)}$ foam cell formation, ${ }^{4)}$ VEGF expression, ${ }^{7)}$ and cholesterol efflux, ${ }^{8,9)}$ thus is believed to exert both pro- and anti-atherogenic effects on macrophages. ${ }^{31)}$ In atherosclerotic lesion development, high concentration of $9(S)$-HODE may exert its atherogenic effect on macrophages by inducing the expression of CD36, a scavenger receptor, which mediates oxidized LDL uptake into macrophages and induces foam cell formation. ${ }^{4)}$ Namely, scavenger receptor substrate, such as oxidized LDL initiates and promotes its own uptake by increasing the level of receptor expression. It is expected that selective PPAR $\gamma$ modulators like FK614 may negatively modulate CD36 expression induced by endogenous ligands and exert an anti-atherogenic effect. As PPAR $\gamma$ agonists are used in type 2 diabetic patients at high risk of developing complications of atherosclerosis, these observations have important clinical implications. Therapeutic benefits of generations of PPAR $\gamma$ ligands in patients with type 2 diabetes could presumably be greatly enhanced by selecting compounds that retain insulin-sensitizing activities and are optimized for their anti-atherogenic activities, ${ }^{31)}$ such as compounds like FK614. FK614 has selective PPAR $\gamma$ partial agonist activity as do previously reported partial agonists, such as troglitazone, ${ }^{13)}$ MCC-555, ${ }^{32}$ GW0072, ${ }^{12)}$ PAT5A, ${ }^{14)}$ and nTZDpa. ${ }^{15)}$ Many of these compounds have potent hypoglycemic and hypotriglyceridemic 
activities in animal models of type 2 diabetes. ${ }^{15,33-35)}$ However, previous studies have not reported whether these compounds negatively modulate PPAR $\gamma$-activity promoted by endogenous ligands, such as 9(S)-HODE. Therefore, FK614 may differ from other selective PPAR $\gamma$ partial agonists, and may have better efficacy as therapy for arteriosclerosis as well as type 2 diabetes.

In relation to diabetes mellitus, it has been reported that heterozygous PPAR $\gamma$ deficient mice are protected from highfat diet-induced insulin resistance. ${ }^{36,37)}$ Consistent with this observation, Pro12Ala polymorphism in human PPAR $\gamma 2$, that moderately reduces transcriptional activity of PPAR $\gamma$, has been shown to confer resistance to type 2 diabetes. ${ }^{38)} \mathrm{Re}-$ cently, appropriate functional antagonism of PPAR $\gamma / \mathrm{RXR}$ by administration of PPAR $\gamma$-antagonist was demonstrated to be a beneficial approach against insulin resistance. ${ }^{39)}$ Therefore maintenance of PPAR $\gamma$ activation in appropriate levels by a PPAR $\gamma$ modulator like FK614 may lead to therapeutic benefits for the control of insulin resistance.

In conclusion, FK614 can bind to PPAR $\gamma$ as an agonist that shows differential properties in coactivator recruitment compared to other TZD ligands, due to distinct conformational changes of PPAR $\gamma$. These distinct properties of FK614 may lead to different biological responses compared to other insulin-sensitizing compounds.

Acknowledgments We thank Drs. Jiro Hirosumi and Hideaki Minoura for reading the manuscript.

\section{REFERENCES}

1) Tontonoz P., Hu E., Graves R. A., Budavari A. I., Spiegelman B. M., Genes Dev., 8, 1224-1234 (1994).

2) Lehmann J. M., Moore L. B., Smith-Oliver T. A., Wilkison W. O. Willson T. M., Kliewer S. A., J. Biol. Chem., 270, 12953-12956 (1995).

3) O'moore-Sullivan T. M., Prins J. B., Med. J. Aust., 176, 381-386 (2002).

4) Nagy L., Tontonoz P., Alvarez J. G., Chen H., Evans R. M., Cell, 93, 229-240 (1998).

5) Lenz M. L., Hughes H., Mitchell J. R., Via D. P., Guyton J. R., Taylor A. A., Gotto A. M., Jr., Smith C. V., J. Lipid Res., 31, 1043-1050 (1990).

6) Harland W. A., Gilbert J. D., Steel G., Brooks C. J., Atherosclerosis, 13, 239-246 (1971)

7) Inoue M., Itoh H., Tanaka T., Chun T. H., Doi K., Fukunaga Y., Sawada N., Yamashita J., Masatsugu K., Saito T., Sakaguchi S., Sone M., Yamahara K., Yurugi T., Nakao K., Arterioscler. Thromb. Vasc. Biol., 21, 560-566 (2001).

8) Moore K. J., Rosen E. D., Fitzgerald M. L., Randow F., Andersson L. P., Altshuler D., Milstone D. S., Mortensen R. M., Spiegelman B. M., Freeman M. W., Nat. Med., 7, 41-47 (2001).

9) Chinetti G., Lestavel S., Bocher V., Remaley A. T., Neve B., Torra I. P., Teissier E., Minnich A., Jaye M., Duverger N., Brewer H. B., Fruchart J. C., Clavey V., Staels B., Nat. Med., 7, 53-58 (2001).

10) Olefsky J. M., J. Clin. Invest., 106, 467-472 (2000).

11) Saltiel A. R., Cell, 104, 517-529 (2001).

12) Oberfield J. L., Collins J. L., Holmes C. P., Goreham D. M., Cooper J. P., Cobb J. E., Lenhard J. M., Hull-Ryde E. A., Mohr C. P., Blanchard S. G., Parks D. J., Moore L. B., Lehmann J. M., Plunket K., Miller A. B., Milburn M. V., Kliewer S. A., Willson T. M., Proc. Natl. Acad. Sci. U.S.A., 96, 6102-6106 (1999).

13) Camp H. S., Li O., Wise S. C., Hong Y. H., Frankowski C. L., Shen X., Vanbogelen R., Leff T., Diabetes, 49, 539-547 (2000).
14) Misra P., Chakrabarti R., Vikramadithyan R. K., Bolusu G., Juluri S., Hiriyan J., Gershome C., Rajjak A., Kashireddy P., Yu S., Surapureddi S., Qi C., Zhu Y. J., Rao M. S., Reddy J. K., Ramanujam R., J. Pharmacol. Exp. Ther, 306, 763-771 (2003).

15) Berger J. P., Petro A. E., Macnaul K. L., Kelly L. J., Zhang B. B., Richards K., Elbrecht A., Johnson B. A., Zhou G., Doebber T. W., Biswas C., Parikh M., Sharma N., Tanen M. R., Thompson G. M. Ventre J., Adams A. D., Mosley R., Surwit R. S., Moller D. E., Mol. Endocrinol., 17, 662-676 (2003).

16) Auwerx J., Diabetologia, 42, 1033 -1049 (1999).

17) Glass C. K., Rosenfeld M. G., Genes Dev., 14, 121-141 (2000).

18) Hörlein A. J., Näär A. M., Heinzel T., Torchia J., Gloss B., Kurokawa R., Ryan A., Kamei Y., Söderström M., Glass C. K., Rosenfeld M. G. Nature (London), 377, 397-404 (1995).

19) Chrivia J. C., Kwok R. P., Lamb N., Hagiwara M., Montminy M. R., Goodman R. H., Nature (London), 365, 855-859 (1993).

20) Oñate S. A., Tsai S. Y., Tsai M. J., O'malley B. W., Science, 270, 1354-1357 (1995).

21) Abraham S. E., Lobo S., Yaciuk P., Wang H. G., Moran E., Oncogene, 8, 1639-1647 (1993).

22) Ogryzko V. V., Schiltz R. L., Russanova V., Howard B. H., Nakatani Y., Cell, 87, 953-959 (1996).

23) Minoura H., Takeshita S., Ita M., Hirosumi J., Mabuchi M., Kawamura I., Nakajima S., Nakayama O., Kayakiri H., Oku T., Ohkubo-Suzuki A., Fukagawa M., Kojo H., Hanioka K., Yamasaki N., Imoto T., Kobayashi Y., Mutoh S., Eur. J. Pharmacol., 494, 273-281 (2004).

24) Elbrecht A., Chen Y., Cullinan C. A., Hayes N., Leibowitz M., Moller D. E., Berger J., Biochem. Biophys. Res. Commun., 224, 431-437 (1996).

25) Cheng Y., Prusoff W. H., Biochem. Pharmacol., 22, 3099-3108 (1973).

26) Nolte R. T., Wisely G. B., Westin S., Cobb J. E., Lambert M. H., Kurokawa R., Rosenfeld M. G., Willson T. M., Glass C. K., Milburn M. V., Nature (London), 395, 137-143 (1998).

27) Xu H. E., Lambert M. H., Montana V. G., Plunket K. D., Moore L. B., Collins J. L., Oplinger J. A., Kliewer S. A., Gampe R. T., Jr., Mckee D. D., Moore J. T., Willson T. M., Proc. Natl. Acad. Sci. U.S.A., 98, 13919-13924 (2001).

28) Berger J., Bailey P., Biswas C., Cullinan C. A., Doebber T. W., Hayes N. S., Saperstein R., Smith R. G., Leibowitz M. D., Endocrinology, 137, 4189-4195 (1996).

29) Brandt M. E., Vickery L. E., J. Biol. Chem., 272, $4843-4849$ (1997).

30) Sasson S., Notides A. C., Mol. Endocrinol., 2, 307-312 (1988).

31) Glass C. K., Witztum J. L., Cell, 104, 503-516 (2001).

32) Reginato M. J., Bailey S. T., Krakow S. L., Minami C., Ishii S., Tanaka H., Lazar M. A., J. Biol. Chem., 273, 32679-32684 (1998).

33) Fujiwara T., Yoshioka S., Yoshioka T., Ushiyama I., Horikoshi H., Diabetes, 37, 1549-1558 (1988).

34) Pickavance L., Widdowson P. S., King P., Ishii S., Tanaka H., Williams G., Br. J. Pharmacol., 125, 767-770 (1998).

35) Vikramadithyan R. K., Chakrabarti R., Misra P., Premkumar M., Kumar S. K., Rao C. S., Ghosh A., Reddy K. N., Uma C., Rajagopalan R., Metabolism, 49, 1417-1423 (2000).

36) Kubota N., Terauchi Y., Miki H., Tamemoto H., Yamauchi T., Komeda K., Satoh S., Nakano R., Ishii C., Sugiyama T., Eto K., Tsubamoto Y., Okuno A., Murakami K., Sekihara H., Hasegawa G., Naito M., Toyoshima Y., Tanaka S., Shiota K., Kitamura T., Fujita T., Ezaki O., Aizawa S., Nagai R., Tobe K., Kimura S., Kadowaki T., Mol. Cell, 4, 597-609 (1999).

37) Miles P. D., Barak Y., He W., Evans R. M., Olefsky J. M., J. Clin. Invest., 105, 287-292 (2000).

38) Deeb S. S., Fajas L., Nemoto M., Pihlajamaki J., Mykkanen L., Kuusisto J., Laakso M., Fujimoto W., Auwerx J., Nat. Genet., 20, 284 287 (1998).

39) Yamauchi T., Waki H., Kamon J., Murakami K., Motojima K. Komeda K., Miki H., Kubota N., Terauchi Y., Tsuchida A., Tsuboyama-Kasaoka N., Yamauchi N., Ide T., Hori W., Kato S., Fukayama M., Akanuma Y., Ezaki O., Itai A., Nagai R., Kimura S., Tobe K., Kagechika H., Shudo K., Kadowaki T., J. Clin. Invest., 108, 10011013 (2001). 